DOI 10.5937/kultura1965121M

УДК 741.5(73)

791.2(73)

оригиналан научни рад

\title{
EKCINIOATALLUA UREJEУCTPИПУ
}

\section{THE PUNISHER}

Сажетак: Cтрип, још у свом повоју, постао је жртва злоупотребе медијских корпоращчја. Шаблонски сценарији су били услов за тиражност и комериијалност а они су, уз „,Comics Code Authority (ССА)", несумьиво највише нашкодили стрипу и успоравали развитак стрипских свезака у високу умјетност. Овај корпорацијски модел, иако проказан и обзнањен јавности још седамдесетих година 20. вијека, није напуштен ни данас. У овом раду ћемо се осврнути на историју индустријализаџије стрипа тј. експлоатаиију оригиналних замисли попут оне у Марвеловом серијалу „Панитер”. Анализа обухвата тридесетрогодишњу еволуичиу серије, опадање квалитета сиенарија и иртежа, као и промјене у карактеру самог Панишера, чиме се покушавају оголити методе којима се врши стварање франшизе од вјештачки одржаваног серијала. Сага о Френку Каслу није најдужа у историји стрипског мегаиздаваштва, али због своје актуелности представља одличан примјер удаљавања стрипа од юегових умјетничких начела.

Кључне ријечи: експлоатација, Марвел, Панишер, Френк Касл, антихерој, хиперпродуктивност, милитаризам

\section{Експлоатаиија идеје}

Мијене у стогодишњем постојању стрипа као медија, како у текстуалном тако и у цртачком погледу, видљиве су и јасне чак и лаику на овом пољу. Стално напредовање узроковано је наслањањем нових идеја на старе и њиховим модификовањем до границе препознатљивости полазне замисли.

До титуле вредноване умјетности, амерички стрип се вратио тежим, трновитијим путем. Дијелом због размажености 
читалаца навиклих на шаблонизирани стрип, а дијелом због отклона према новим идејама (гајеном од стране оних који су склони посматрању сваког вида популарне културе као пуке забаве), у колијевци модерне девете умјетности, Сједињеним Америчким Државама, средином прошлог вијека се изградило увријежено мишљење да добитну комбинацију за освајање читалаца аутори и издавачи не смију мијењати. Овим потезом покушао се остварити већи профит без обзира на то што ће квалитет стрипа опадати са сваким новим бројем. Не дозвољавајући скоро никакве осцилације и одступања од утврђеног концепта, челници издавачких кућа свјесно су приступали инфантилизацији стрипа. ${ }^{1}$

Познатије свјетске стрип куће су само слиједиле дати примјер новинских магната, који су се након индустријализације филма и књижевности, окренули комерцијализацији стрипа, који је већ почетком 20. века, у свом платинастом, а касније од 1930-их у златном добу, ${ }^{2}$ из забавног штива израстао у конкурентну медијску форму. Желећи се окористити његовом популарношћу код јавним гласилима несклоног млађег нараштаја, горепоменути су осамосталили стрип његовим премјештањем из новина и часописа у засебне и само стрипу посвећене свешчице (comic books). Овим потезом се омогућила масовна производња стрипова али је он потраживао и трајан рецепт за опстанак на тржишту. Један од њих био је и унајмљивање популарних списатеља за писање сценарија, ${ }^{3}$ чија су имена требала одстранити колебљивост купца свешчице. Инјектирањем обрасца нестрипских

1 Потврда оваквог начина рада се може пронаћи и у одговору Џоа Орланда (Joe Orlando), дугогодишњег уредника Детектив комикса, на питање да ли његово предузеће планира и неко издање за 'одраслију' публику: „Одраслија публика? Не, немам планова за тако нешто. За сада не видим разлоге. Хоћемо да се обраћамо младим читаоцима, ићи ћемо све више ка млађим, радимо на пројекту стрип-играчки. [...] Сви се чуде прихваћености супер-хероја од публике, добро се продају. Знам да се у Европи стрипови обраћају више одраслим читаоцима, код нас је другачије, пошто се стрип третира као јувенилна литература. Једини разлог што се још и сада обраћа пажња на стрипове је тржишна вредност, а не због уметничке форме. Прихваћеност и квалитет се мери приходом [...] Читачи стрипа кад одрасту, траже старе стрипове из младости, у стању су да плате стотине долара за предратна и друга стара издања. Супермен се цени зато што прави велике паре, а не зато што је уметничко дело." Đukić, B. (1981) To je crtač... to je urednik... to je Džoe Orlando, YU strip br. 35, Gornji Milanovac: Dečje novine, str. 23-24.

2 Златним добом америчког стрипа назива се период од 1938. до 1956. године. Више о томе у: Plummer, J. What is the Golden age?, 17. may 2017. 1. july 2019., https://bookriot.com/2017/05/17/what-is-the-golden-age/.

3 На примјер, тридесетих година прошлог вијека су за сценарио стрипа „Тајни агент X-9” (Secret Agent X-9) били задужени Дешајел Хемет (Dashiell Hammett) и Лесли Чартерис (Leslie Charteris). 


\section{МИЛАН МИЛОШЕВИЋ}

серија, растеретили су се понекад сценаристи, али свођење радње на клишетска рјешења и неубједљиве заплете успорили су нову легитимизацију америчког стрипа међу „високе" умјетности, мада ни приближно колико и цензорски код 4 или пропагандно-ангажовани стрип. ${ }^{5}$

Прекоокеанска популарност Марвелових и Детектив комикс суперхероја, условила је ширење раздора између оних који стрип сматрају забавним штивом и оних који га називају умјетношћу. Поларизацију у порасту и предњачење европских пројеката покушао је, између осталих, умањити визионар Нил Адамс ${ }^{6}$ (Neal Adams) али за његове иновације амерички стрипски (сада већ) трустови нису марили. Комерцијалне трендове у масовној продукцији јефтине забаве најбоље ћемо осликати повлачењем паралеле са закључцима Артура Хејлија (Arthur Hailey) у роману Котачи (Wheels, 1971), гдје hе овај писац упоредити квалитет два реномирана произвођача возила са различитих континената. Хејли, бавећи се у поменутом роману проблемима Џенерал моторса (General Motors), наводи да су возила произведена у детроитском гиганту лоша јер их склапају безвољни и слабо плаћени људи који у нељудским условима покушавају да постигну дневну норму. Насупрот њима стоји, примјерице, један Мерцедес (Mercedes-Benz) чији радници на годишњем нивоу направе двоструко мањи број аутомобила, али их пажљиво и с поносом склапају јер су она за њих умјетничко дјело. Овај навод потцртава постојеће супарништво

4 Comics Code Authority (CCA) је цензорски модел надзора стрипова у складу са моралним и законским назорима, утемељен у САД 1954. године. На српском: CCA (1975) Kodeks američkog udruženja izdavača stripova, превела Гордана Велмар-Јанковић, у: Култура, бр. 28, темат „Strip - deveta umetnost?”, приредио Ранко Мунитић, Београд: Завод за проучавање културног развитка, стр. 261-265; Видети такође: Đukić, В. M. (1987) Prijeti li američkom stripu (ponovo) progon, Oscar br. 2, Bjelovar: Čvor, str. 34-35. Daniels, L. (1988) Comix - A history of comic books in America, New York: Random House, посебно: Chapter 5: „The Comics Code controversy", pp. 83-90. Nyberg, A. K. The Comics Code, in: The Routledge companion to comics, edited by Bramlett, F., Cook, R. T. and Meskin, A. (2017), New York: Routledge (e-edition).

5 Не смије се пренебрегнути чињеница да је у Другом свјетском рату стрип био јако пропагандно средство америчког милитаристичког апарата. Исти модел налазимо и у сваком наредном сукобу већих размјера (Кореја, Вијетнам, Никарагва). Негативно на ниво умјетничког у суперхеројским стриповима знатно утиче и ангажованост њихових јунака у „стварном» свијету, нпр. пројекти Heroes against hunger (Супермен и Бетмен против глади у Африци) и Deadly legacy / Смртоносно завештање (Супермен спашава необазриву дјецу у Босни од нагазних мина).

6 Đukić, B. (1987) Nil Adams - večiti dečak američkog stripa, Stripoteka br. 906, Novi Sad: Marketprint, str. 3-5. 
између европског и америчког стрипа те ближе појашњава њихова различита усмјерења.

\section{Панишер}

Због увријеженог мишљења у САД о стрипу као пријемчивијем виду забаве за све оне којима је мрско читати дуге, замршене романе класичних аутора, није му било лако изаћи из културне нише нижеразредног, „петпарачког” штива. Дневни каишеви синдикатског стрипа, рани европски (авантуристички и карикатурални) стрип као и суперхеројске „тракавице” представљају темељ свеукупне свјетске стрип баштине и њихова образовна улога за најмлађе читаоце се не смије пренебрегнути. Постављен је одређени стандард који су стрипски радници морали поштовати ако су, поред тржишности, жељели да се и њихово дијело цијени. Један дио власника и инвеститора издавачких кућа се опредијелио само за финансијску страну па је масовном производњом деградирао поетику стрипа предвидљивошћу садржаја, повлађивањем циљаној публици и непостојаношћу темеља основне приче. Индустријским разводњивањем и кратким роковима за цртаче 7 , ни визуелни дио није остајао поштеђен па су неке епизоде реномираних серијала више подсјећале на скице него на квалитетну и скупо плаћену таблу стрипа.

Иако корпорационизам у стрипу није само болест америчких мегаиздавача (италијански пример је Алан Форд - Alan Ford), пад у квалитету дугогодишњих серијала са мјесечним темпом изласка, најпримјетнији је баш у Сједињеним Државама. Све мане непропорционалне експлоатације добре замисли налазимо у Марвеловим и Детектив комикс издањима, и то махом у суперхеројским насловима. Провидност стварања ликова попут Жене Паука (Spider-Woman) и Капетана Британије (Captain Britain) је очита и више дјелује као потез немаштовитих почетника него као пројекат озбиљне издавачке куће. Изреченом пријеком суду претпостављамо један од Марвелових експеримената, Панишера, наслов који је осјетио и добре и лоше стране манипулације (не)укусом а чија је основна порука атрофирала под теретом хиперпродуктивности.

Панишер (срп. Казнилац, Казнатељ) је антијунак Марвеловог свемира, који ће својом појавом у америчком стрипу

7 У новинском синдикалном стрипу је у једној седмици требало изнаћи рјешење за шест дневних и недјељну таблу. 
постати прво преседан ${ }^{89}$, а затим правило стотинама пута. ${ }^{10}$ Он је исто тако добар примјер преваге мрачне стране људског разума, мијене у читалачком укусу младих као што је добар примјер издавачке безидејности.

Створен као једнобројна напаст али и лак противник за Човјека Паука (Spider-man), Панишер је требао послужити само као кратак предах између безбројних повратака Паукових вјечних непријатеља, Доктор Октопуса (Doctor Octopus) и Гоблина (Green Goblin). Ипак, овај „сумашедши” официр, послије увођења „на мала врата” у јавност (1974) и пар година таворења у ладици радног стола познатог Марвеловог уредника Стен Лија (Stan Lee), 1986. године бива представљен јавности кратким серијалом Кругови крви. ${ }^{11}$ Почетних пет епизода (по критичарима и најбољи урадак који је овај серијал имао), представљају нам Френка Касла (Frank Castle) у улози најозлоглашенијег затвореника затвора на острву Рајкер, који нам у првом лицу даје опис свог унутрашњег стања и бијегом из “нездраве околине” најављује будућа чишћења градских улица од разних напасника.

У деценији популарности акционих филмова, пуних насиља и пролијевања крви, уводни серијал се допао публици која је добро прихватила једног отпадника од закона за насловног јунака. Панишер је Френк Касл, бивши маринац, машина за убијање, који се, завршивши ратовање у вијетнамским прашумама, вратио кући. Игром судбине, двије мафијашке банде су за обрачун изабрале парк у којем је породица Касл организовала излет па се ова, потпуно недужна, нашла у унакрсној паљби. Трагедију преживљава само Френк и послије годину дана полицијског неуспјеха у потрази за починиоцима гнусног злочина над његовим најмилијима, одлучује се за професију самозваног џелата пријеког суда. Већ тад психички неуравнотежен, Френк израђује мајицу са злокобном лобањом и (нетипично за Марвелове јунаке) креће у рат са криминалцима без маске која би му прикрила идентитет. Стечено знање о оружју и стратегији га је учинило изузетно

8 Martin, M. A. The Punisher, in: The superhero book: The ultimate encyclopedia of comic-book icons and Hollywood heroes, edited by Misiroglu, G. with Roach, D. A. (2004) Detroit: Visible Ink, pp. 395-397.

9 Coogan, P. (2006) Superhero: The secret origin of a genre, Austin: MonkeyBrain Books, pp. 54, 216.

10 Weiner, R. G. (2008) Marvel Graphic Novels and Related Publications: An Annotated Guide to Comics, Prose Novels, Children's Books, Articles, Criticism and Reference Works, 1965-2005, Jefferson, North Carolina, and London: McFarland \& Company, Inc.

11 Иако су Кругови крви (Circle of blood) само наслов хронолошки прве епизоде у петобројном волумен - у The Punisher, по њој се назива читава серија прича о Френку Каслу из 1986. године. 
опасним по полусвијет у којем је веома брзо стекао репутацију Божије казне. Његова незаконита изрицања смртне пресуде изван суднице Врховног суда, бивају благонаклоно посматрана од стране поштених полицајаца, који су, омеђени законима, немоћни пред потплаћеним шефовима и несавјесним адвокатима.

Иако му полицајци прећутно дају за право, јер ради прљави посао умјесто њих, Френк Касл је бјегунац који се мора крити по напуштеним складиштима и хангарима, преуређеним у праве футуристичке оружарнице. Као човјек од акције али не и познавалац модерне технологије, Касл (сад већ увелико Панишер) са собом вуче искусног програмера и изумитеља Микрочипа (Microchip), који се свесрдно залаже за заједнички циљ - од криминалаца чист град.

На просјечно 22 странице до почетка 2019. године изашло је око 500 епизода Панишер франшизе (War journal; The Punisher vol. 1-10; Punisher: War zone vol. 1-3; PunisherMAX; годишња и божићна специјална издања, велики број тзв. опе shot-ова и пропратних spin-off серијала). Угасивши Екс алманах 1989. године, горњомилановачке Дечје новине су покренуле три мјесечне едиције у којима ће се објављивати изабрани амерички стрипови. Панишер је, у конкуренцији са Дистројером (Destroyer) и Конаном (Conan), изгубио трку од допадљивог варварина па је нашој читалачкој публици у деведесетим годинама прошлог вијека остао познат тек као кратковјечан серијал од девет бројева. Послије обнове стрип тржишта у бившим југословенским државама, ниједан издавач није показао занимање за макар интегрално објављивање овог серијала. ${ }^{12}$

Заведени успјехом Кругова крви, Марвел је наставио серијал и већ сљедеће, 1987. године проширио радњу у едицију The Punisher vol. 2. У њој налазимо приземне детективске теме из петпарачких криминалистичких романа у којима Френк Касл, попут Џејмса Бонда (James Bond) са проширеним то$d$ us operand $i$-јем, бива опреман футуристичким оружјем од стране компјутерског мага и свезналице Микрочипа. Лајнус Либерман (Linus Lieberman) звани Микрочип, потпора Панишеру налик Бетменовом батлеру Алфреду, ознака је бенигнијег дијела серијала и једини прави сарадник којег је Касл истрпио до краја едиције (1995).

У стотињак бројева ове серије налазимо причљивог и ментално стабилног Касла, који елиминацију криминалаца

12 Објављивањем интегралног издања Marvel Essential: Panišer (Čarobna knjiga, 2016), Френк Касл се вратио на наше просторе након двадесетшестогодишњег одсуства. 
доживљава као свакодневни и законит посао. Реалистичност радње поништава а инфантилност повећава, поред стереотипних дијалога, слаба мотивација поступака код злочинаца и ултратешко наоружање, с којим се Панишер, без видног напора, вере по зградама мегалополиса у потрази за злочинцима. Од мноштва „рупа” у сценарију потребно је одабрати ону која је у едицији најпримјетнија а то је: повратак упечатљивих негативаца. Неинвентивност се, као хронична Марвелова бољка, испољила и на овом несуперхеројском пројекту. У 104 броја мафијаш са унакаженим лицем Тестерица (Jigsaw) је враћен у живот чак шест пута! Овај детаљ угрожава концепт стрипа али и его лика познатог по педантности у извршавању свог „посла”. Цртачки, овај том, изразито слабо стоји. И поред палете радника на свакој епизоди, већина их оставља утисак крајњег аматеризма што читаоца мора навести на помисао о драстичном паду квалитета у поређењу са цртежом Џона Ромите Старијег (John Romita Sr. $)^{13}$.

Угасивши Volume 2, наставило се са уназађивањем серијала вођењем Панишера кроз разна путешествија. Послије осуде због убиства Ника Фјурија (Nick Fury), изгубио је памћење, извршио самоубиство па га преживио, као и удружене нападе на своје постојање Небојше (Dardevil), Волверина (Wolverine) и Човјека Паука. Кратко је био и с друге стране закона и то у улози мафијашког дона (The Punisher vol. 3). Серијал и едиције у периоду од 1995. до 2004. године опстају на дугометражним акционим заплетима („пуцачинама”) везаним за неки занимљив а дотад недодирнут дио из Касловог живота. Тако су вјештачки одржавали франшизу са нпр. унајмљивањем плаћеног убице који личи на Каслову покојну супругу Марију или причом о рађању убилачког инстикта у Френку током боравка на вијетнамском ратишту (Born).

Ситуација се дјелимично поправља са преласком Панишера под фирму Мax, иначе Марвелову испоставу. Од марта 2004. године серијал носи ознаку Parental advisory због експлицитних сцена насиља, сексуалног иживљавања, али и милитаристичког фетишизма, који се и не покушава прикрити. ${ }^{14}$ Наративно ваљанија црта серије се поново почела назирати са логичним слиједом у помраченој свијести Френка Касла. Послије Микрочипове предаје Панишера закону (у страху од његовог очигледног уживања у убијању), наш се ,„јунак”

\footnotetext{
13 Илустратор Кругова крви.
}

14 Периодично се издавао илустровани додатак о оружју које користи Панишер са вјеродостојним објашњењима. 
послије губитка јединог пријатеља, повлачи у себе и у сталном бијегу преживљава још пар „сигурних” смрти (у неких стотинак свесака). Превагнувши из осветника и полицајца са посебним овлашћењима у психотичног манијака због пријатељеве издаје, потпуно је мотивисан процес и послије десетак година приповиједне кризе можемо рећи да је овај серијал добио, макар на кратко, на увјерљивости.

Подмлађивањем редакције, сценаристички посматрано, серијал је кренуо узлазном путањом. Ипак, ни овај узлет прожет насиљем није потрајао дуго јер се уредништво оптеретило сталним потрагама за новим, неприказаним начинима мучења жртава као и Панишеру достојних противника. Вриједан помена је сигурно Енисов (Garth Ennis) и Парловљев лик Баракуда (Barracuda) чија убједљивост је подстакла издаваче да покрену spin-off мини-серијал посвећен њему (Punisher Max Presents: Barracuda). Пуко насиље, поетички необликовано у достојну сценаристику, није формула за трајно придобијање публике па је тако и The Punisher MAX отишао у историју са бројем 75.

Удаљавање од реалистичности серијала (самим тим и квалитета приповиједања), наставило се у 2009. години са одлуком да се Панишер убаци у неки од многих суперхеројских универзума гдје ће се заједно са надљудима борити за уобичајену тему америчких блокбастера и стрипова - спас свијета. Замешатељство ствара Мах са покретањем нове серије у којој ће Френк Касл имати приземнију улогу - убијање Кингпина (Kingpin). Истовремено преплитање двије линије исте приче је стандардно за амерички систем пласмана али с њим се озбиљно удара на потенцијал и јаче сторије него што нам је понуђена са другом серијом Punisher MAX-a. Френков сукоб са Кингпиновим тјелохранитељима Метом (Bullseye) и Електром (Electra) те лична драма врховног шефа њујоршке мафије Вилсона Фиска (Wilson Fisk) је, иако продужен до максимума (22 епизоде), једна од солиднијих линија ове франшизе.

Потоње мини-серије су одлични докази немоћи америчких мегаиздавача да изњедре нешто ново са чим би оживјели вегетирајући серијал. Још једно у низу таквих рјешења је било убацивање идејно истрошеног јунака у временску „црвоточину" и његово слање у будућност ${ }^{15}$ (The Punisher 2099 AD) али и прошлост (Punisher: Noir). Да наш осветник понекад

15 Када серијалу опадне продаја, издавачке куће се одлучују и на овакве потезе. Први антихерој послат у будућност био је револвераш Џонах Хекс (Jonah Hex), узданица Детектив комикса. То је учињено 1985. године за потребе серијала Нех. 
узима и слободан дан доказују нам специјална издања у којима се Панишер на Божић нерадо одлучује да сређује рачуне са криминалцима (The Punisher: Red X-mas и The Punisher: X-Mas Special).

Да би избјегли једноличност објеката великих градова, уредници су често измјештали мјесто радње у јужноамеричке џунгле, сибирски лед и блискоисточне пустиње. Смјештање фиктивног лика у постојећу ситуацију, којом су се хтјеле сугерисати добре намјере обичних Американаца (већ поменута памфлет-акција Супермен против Глади), није мимоишло ни овај стрип па је и Панишер, након Супермена, свратио у Босну и Херцеговину. Пратећи траг међународног трговца оружјем Викадија (Vikady), Касл је пристигао у Сарајево из којег је, не снашавши се у сукобу „сви против свих", побјегао без гајења илузија да је он, као ратни ветеран, дорастао таквом сукобу. ${ }^{16}$ Занимљиво је да је за ову дводјелну епизоду (The Punisher War Zone n. 35-36) унајмљен Џо Куберт (Joe Kubert), који је у овом „босанском двоброју”, својим цртачким умијећем, ријетко виђеним у комплетној франшизи успио непристрасно ${ }^{17}$ да демонстрира погубност ратног механизма по човјеков ум и опстанак људске заједнице.

Међу упитне уредничке одлуке убројаћемо и Панишерово старење. Неодредива старост јунака јесте чест проблем у дугогодишњим серијалима а овдје је она различита од тома до тома. Међу подмлађеним Марвеловим јунацима нашао се и Панишер па чести прикази акробација непримјерених тјелесним могућностима једног шездесетогодишњака представљају артефакт више у корист тезе о америчком нереалистичком димензионирању људске физичке спремности. Примијетна је и недосљедност у избору смрти за Панишера. Петнаестак различитих видова његове смрти нису биле довољне па су неке едиције завршиле са остављањем читаоца у недоумици да ли је Панишер умро од рана задобијених у још једној самоубилачкој акцији у његовом стилу „сам против свих” или га је опет неко од „поштених цивила” спасио. Ипак, у мору једноличних и једнократних епизода, издваја се она велемајстора Ричарда Корбена (Richard Corben) -

$16 »$ This isn't my war. My war's got rules i understand. My war is me against them. There's no rules here. No lines. No black. No white. [...] / - Time to go home. / New York's going to seem like Disneyland after this trip.« Children of the Gun (1995) The Punisher War Zone n. 36, New York: Marvel, p. 22.

17 Ако изузмемо забуне у именима - муслимански герилци се зову Митар и Јосип - финални дио саге Ријека крви (River of blood) својим текстом и поруком сигурно неће бити предмет осуде ниједне стране учесника грађанског рата у Босни и Херцеговини. 
The Punisher: The End - у којој нам отац Бладстара (Bloodstar), Света мутаната (Mutant World) и Дена (Den) cepвира одличну постапокалиптичну причу Гарта Ениса о посљедњим данима Панишера, сада остарјелог затвореника у бијегу.

Манир екранизације стрипова у осамдесетим годинама прошлог вијека није заобишао ни Панишера па је Марвел, послије бледуњаве верзије из 1989. Године, ${ }^{18}$ у новом миленијуму приредио још двије, ${ }^{19}$ приповиједно нимало боље. Рачунајући на млађу публику, продуценти су напустили хронолошки ток и потпуно одбацили основни сценарио, уништивши тако вишегодишњу разраду карактера Френка Касла. Ни лоше критике гледалаца филмова о Панишеру нису биле довољне да се заврши индустријско експлоатисање ове замисли па тако у 2019. години, имамо нове стрипске и телевизијску серију. ${ }^{20}$

\section{Назире ли се крај лошем тренду?}

У овом прегледу тридесетогодишњици Марвеловог серијала Панишер, покушали смо приказати експлоататорски однос према стрипу. Мада је овај начин исцрпљивања потенцијала једне добре идеје већ озбиљно нагризао и темеље европског стрипа (Астерикс - Asterix; Талични Tом - Lucky Luke), мање озбиљан приступ ,рестаурацији”, ипак везујемо за америчке сценаристе. Панишер је један од стрипова чији је потенцијал у потпуности искоришћен већ у његовом „пубертету" и чијем се експлоатисању још не назире крај. „Теме су се можда и удаљиле од типичног Марвеловог дијапазона, али неизмјењени, преискушани, преексплоатирани приступ, драматургија и карактерологија ту су као и у сваком другом типичном Марвеловом издању (...) Њихова махом дјечја публика тешко се може даље варати и мамити, (...) а одрасли се не могу поново привући формулама које упорно остају на старим, више него познатим рецептима". ${ }^{21}$

Ваља назначити да чедо Џерарда Конвеја (Gerard Convay) неће прекрити паучина Марвелове архиве јер је Панишер постао симбол слободног Американца који, испод јужњачке заставе, узгаја култ оружја и самоодбране те сам штити своју породицу. Милитаристичка нота овог стрипа је најчешћи

18 Goldblatt, M. (1989) The Punisher, New World International.

19 Hensleigh, J. (2004) The Punisher, Lionsgate films and Lexi, A. (2008), Punisher: War Zone, Lionsgate films.

20 Lightfoot, S. (2017) The Punisher, Netflix.

21 Đukić, B. (1987) Marvelov novi univerzum, RS Magazin br. 87/2, Zagreb: Vjesnik, str. 98. 


\section{МИЛАН МИЛОШЕВИЋ}

разлог његове злоупотребе па се сви они који бесједе о упитном утицају стрипова оправдано прибојавају његовог ефекта. Инерција би могла донети нови квалитативни и суноврат Панишеровог стрипа кроз стрип, филм и играчке, јер су неки модерни конзументи популарне културе спремни прогутати и духовно неукусније штиво, ако је на омоту свеске амблем Марвела.

\section{ИЗВОРИ:}

\section{Cmpип и проза:}

Dečje novine (1990) Punisher magazine, n. 1-5, Gornji Milanovac. Marvel (1986) The Punisher, n. 1-5, New York.

Marvel (1987-1995) The Punisher, n. 1-104, New York.

Marvel (1988-1995) The Punisher War journal, n. 1-80, New York. Marvel (1992-1995) The Punisher War zone, n. 1-41, New York Marvel (1995-1997) Punisher, n. 1-18, New York.

Marvel (1995) Punisher kills the Marvel Universe, New York.

Marvel (1998-1999) The Punisher, n. 1-4, New York.

Marvel (2000-2001) The Punisher, n. 1-12, New York.

Marvel (2001-2004) The Punisher, n. 1-37, New York.

Marvel (2005) The Punisher: Red X-Mas, New York.

Marvel (2009) Punisher: The Noir, n. 1-4, New York.

Marvel (2013) Punisher: Trial of the Punisher, n. 1-2, New York.

MAX (2004-2009) The Punisher, n. 1-75, New York.

MAX (2010-2012) PunisherMAX, n. 1-22, New York.

MAX (2003) Born, n. 1-4, New York.

MAX (2004) Punisher: The End, New York.

MAX (2007) Punisher MAX Presents: Barracuda, n. 1-5, New York.

MAX (2012) Untold tales of the Punisher MAX, n. 1-5, New York.

Hailey, A. (1986) Kotači, Zagreb: Mladost.

Филм:

Goldblatt, M. (1989) The Punisher, New World International.

Hensleigh, J. (2004) The Punisher, Lionsgate films.

Lexi, A. (2008) Punisher: War Zone, Lionsgate films.

Lightfoot, S. (2017) The Punisher, Netflix. 


\section{МИЛАН МИЛОШЕВИЋ}

\section{ЛИТЕРАТУРА:}

CCA (1975) Kodeks američkog udruženja izdavača stripova, превела Гордана Велмар-Јанковић, у: Култура, бр. 28, тема „Strip - deveta umetnost?“, приредио Ранко Мунитић, Београд: Завод за проучавање културног развитка, стр. 261-265.

Coogan, P. (2006) Superhero: The secret origin of a genre, Austin: MonkeyBrain Books.

Daniels, L. (1988) Comix - A history of comic books in America, New York: Random House.

Đukić, B. M. (1981) To je crtač... to je urednik... to je Džoe Orlando, YU strip br. 35, Gornji Milanovac: Dečje novine, str. 23-24.

Đukić, B. M. (1981) Zahvaćen Marvel-manijom, YU strip br. 31, Gornji Milanovac, str. 31-32.

Đukić, B. M. (1987) Marvelov novi univerzum, RS Magazin br. 87/2, Zagreb: Vjesnik.

Đukić, B. M. (1987) Nil Adams - večiti dečak američkog stripa, Stripoteka br. 906, Novi Sad: Marketprint, str. 3-5.

Đukić, B. M. (1987) Prijeti li američkom stripu (ponovo) progon, Oscar br. 2, Bjelovar: Čvor, str. 34-35.

Howe, S. (2013) Marvel Comics: The Untold Story, New York: Harper Perennial.

Kaveney, R. (2008) Superheroes! Capes and Crusaders in Comics and Films, London: I. B. Tauris \& Co Ltd.

Martin, M. A. The Punisher. In: The superhero book: The ultimate encyclopedia of comic-book icons and Hollywood heroes, Edited by Gina Misiroglu with David A. Roach (2004) Detroit: Visible Ink, pp. 395-397.

Nyberg, A. K. The Comics Code, in: The Routledge companion to comics, edited by Bramlett, F. Cook, R. T. and Meskin, A. (2017), New York: Routledge (e-edition).

Plummer, J. What is the Golden age?, 17. may 2017., 1. july 2019., https://bookriot.com/2017/05/17/what-is-the-golden-age/.

Smith, M. J. Superhero Comics, in: The Routledge companion to comics, edited by Bramlett, F. Cook, R. T. and Meskin, A. (2017), New York: Routledge (e-edition).

Weiner R. G. (2008) Marvel Graphic Novels and Related Publications: An Annotated Guide to Comics, Prose Novels, Children's Books, Articles, Criticism and Reference Works, 1965-2005, Jefferson, North Carolina, and London: McFarland \& Company, Inc. 


\title{
МИЛАН МИЛОШЕВИЋ
}

\author{
Milan Milošević \\ University in Belgrade, Faculty of Philology, Belgrade
}

\section{IDEA OF EXPLOITATION IN COMIC BOOKS}

\section{THE PUNISHER}

\begin{abstract}
Since their appearance, comic books have been victims of misuse by media concerns. Generic plotlines were preconditions for large printings, which - alongside commercialization and the Comics Code Authority (CCA) - without a doubt did the most damage to comic books and hindered transition of the once humorous newspaper addition into a genuine art form. Though the corporate model was well known and derided even during the 1970s, it has persisted to this day. This paper examines comic book industrialization and exploitation of original ideas. The analysis centers on the evolution of Marvel's Punisher series. Following the decrease in quality of writing and drawing, as well as the changes made to the character of Punisher himself, the paper exposes the methods with which franchises are created from otherwise artificially maintained properties. Saga of Frank Castle is not the longest run in mass-produced comic book publishing history, but it is still a potent example of cultural trends and the divergence of comic books from their artistic principles.
\end{abstract}

Key words: idea exploitation, Marvel, The Punisher, Frank Castle, antihero, hyper productivity, militarism

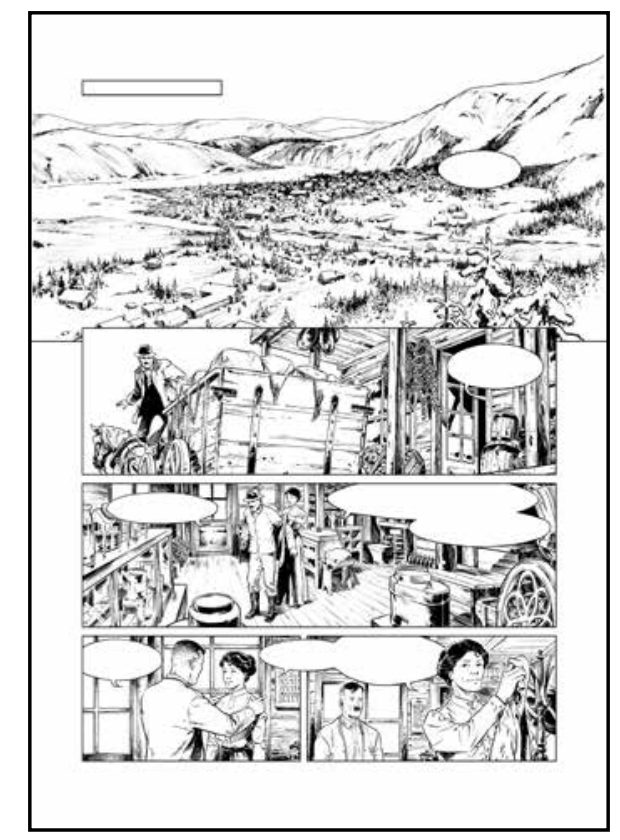

Синиша Радовић, Fille du Yukon-Eldoradores, перо и туш, 2007. 